\title{
ERMR System - an Useful Tool In Defining of Technology for Excavation
}

\author{
Milorad Jovanovski \\ Faculty of Civil Engeneering \\ Skopje \\ Macedonia \\ jovanovski@gf.ukim.edu.mk
}

\author{
Valentina Žileska Pančovska \\ Department of technology and \\ organization of construction Skopje \\ Macedonia \\ valentinazp@gf.ukim.edu.mk
}

Igor Peshevski
Faculty of Civil Engeneering
Skopje
Macedonia
peshevskii@gf.ukim.edu.mk
DOI 10.5592/otmcj.2011.2.3

Research paper

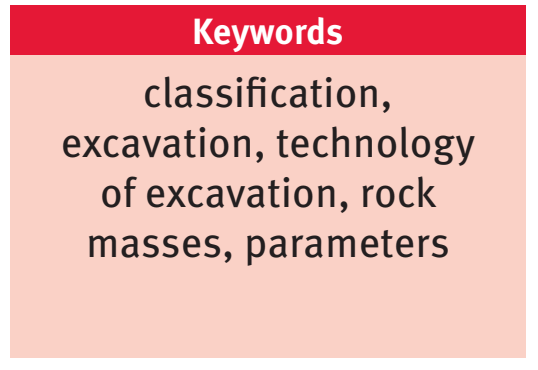

THIS ARTICLE PRESENTS THE BASIS OF CLASSIFICATION SYSTEM NAMED as Excavation Rock Mass Rating System (ERMR). The purpose for system development comes from the fact that in all civil engineering or minning projects, one of the key problems is to addopt technology of excavation on the characterisstics of natural environment, and to chosse and adequate equipement for excavation.

Methodology for establishing of ERMR system is based on ranking and scoring of careffuly choosen classification parameters. The parameters for classification and the range of parameters in each class is explained briefly. The system is correlated with some known rating rock mass systems.

The classification is developed on the bases of numerous investigations for different civil engineering and mining projects, as well as laboratory testings of rock mass parameters. The case histories used in developing of the ERMR system are noted. For each rock mass class, an adequate technology of excavation is suggested, and the excavation classes are corelated with unit price of excavation in different media.

The practical aplication of ERMR system is undelined.

\section{INTRODUCTION}

Predicting the ease of excavation of rock and rock masses is very significant for defining of technology and organisation of earthworks for civil engineering works and in surface mines.

On this important scientific and practical field, several authors gave effort to establish acceptable methodologies for practical use (Franklin et al., 1971), (Atkinson, 1971), (Weaver, 1975), (Kirsten, 1982), (Abdullatif and Cruden,
1983), (Scoble and Muftuoglu, 1984), (Pettifer and Fookes, 1994), (McLean and Gribble, 1985), (Singh et al., 1987), (Church, 1981) and another's. The reference that gives whole overview on this aspect is given by Tsiambaos and Saroglou (2009)

In the present article, the term excavatability is used to determine the ease of excavation of rock and rock masses that includes the methods of digging, ripping and blasting. 
In general, methods used for the assessment of excavatability of rock masses take into account the uniaxial compressive strength, weathering degree, spacing of discontinuities, hardness, seismic velocity, continuity, aperture, orientation and roughness of joints etc. Any how, no particular method is universally accepted because of complex nature of rock masses and difficulties in determining of input parameters.

Having this in mind, a classification system called ERMR (Excavation Rock Mass Rating) is presented. It refers to all types of rock masses (non-coherent and coferent soils as well as weak and hard rocks).

The classification is developed on the bases of numerous investigations for different structures, in order to create prerequisites for over passing of current situation in world practice, where classifying of rock mass for excavation is insufficiently developed.

\section{Principles of formation of the ermr system}

The system is based on scoring, where the selection of parameters is done respecting the next principles:
- Input parameters can be obtained with quick and relatively simple tests;

- The parameters should be relevant for the properties of the rock masses;

- The same property should not be taken into the evaluation two or more times.

During selection of input parameters, it was taken in care all of them to be enough representative for the characteristics of the massive and intact rock parts.

As characteristics of the intact rock the next parameters can be considered:

- Uniaxial compresive strength (oc) or Point Load Strentgh index (Js) alternatively;

- Unit weight $(\mathrm{\gamma})$;

- Hardness, which can be qualitatively expressed trough the Moss scale relative hardness (M) and quantitatively with value of Schmith Hammer Rebound Value (SHRV), using correlation $\mathrm{SHRV}=8.72 \mathrm{M}-0.04$.

Characteristics of rock massif are presented with the next parameters:
Degree of fracturing using average fracture spacing (Ls) or as alternative with rock quality designation parameter (RQD)

- Condition of fracture walls (continuity, aperture, roughness, infill material etc).

The effects of the orientation of discontinuities can be important for metamorphic rock masses and sedimentary flysch sediments, where the anisotropy is strongly expressed.

As an example, it is well known that most favourable conditions for ripping are if the direction of pushing of the bulldozer is perpendicular to the foliation and when the foliation itself has a steep dip angle. These dilemmas can be solved if we apply measurements and testing in this manner:

- Testing of anisotropy for intact rock parts;

- Defining of anisotropy of fracturing;

- Defining of the optimal orientation of excavation, and scoring of strength and fracturing in relation to possible direction of excavation.

Database of input parameters that served for the development of ERMR system and applied excavation method for analysed cases is given in Table 1. 


\begin{tabular}{|c|c|c|c|c|c|c|c|c|}
\hline No & Structure & Rock type & $\begin{array}{l}\text { Fractu-re } \\
\text { spacingLs } \\
\quad(\mathrm{cm})\end{array}$ & $\begin{array}{l}\text { RQD } \\
(\%)\end{array}$ & $\begin{array}{c}\text { Unit weight } \\
\gamma \\
\left(\mathrm{KN} / \mathrm{m}^{3}\right)\end{array}$ & $\begin{array}{l}\text { Compressive } \\
\text { strength }\left(\sigma c^{\star}\right) \text { or } \\
\text { Point Load strength } \\
\text { index Js** }(\mathrm{MPa})\end{array}$ & $\begin{array}{l}\text { Hardness } \\
\text { (Moss scale) }\end{array}$ & $\begin{array}{l}\text { Applied } \\
\text { excavation } \\
\text { method }\end{array}$ \\
\hline 1 & $\begin{array}{l}\text { Surface coal mine } \\
\text { Suvodol (SCMS) }\end{array}$ & Silt stone (trepel) & 10 & 22 & Average 15 & $0.155^{-1.2^{*}}$ & $1-1.5$ & Rotary dredger \\
\hline 2 & SCMS & Siltstone (trepel) & 200 & 100 & Average 15 & $0.155^{-1.2} 2^{*}$ & $1-1.5$ & Rotary dredger \\
\hline 3 & SCMS & Coal & 20 & $50-75$ & Average 12 & $3-6^{*}$ & $1-1.5$ & Rotary dredger \\
\hline 4 & $(\mathrm{SCMS})$ & Coal & 200 & 100 & Average 12 & $3-6^{*}$ & $1-1.5$ & Rotary dredger \\
\hline 5 & $\begin{array}{c}\text { Railway Kumanovo-Deve } \\
\text { Bair (RKD) }\end{array}$ & Tuff & $\begin{array}{l}\text { massive } \\
200 \mathrm{~cm}\end{array}$ & 100 & $20.8-22$ & $3 \cdot 21-4 \cdot 1^{*}$ & 2 & Digging \\
\hline 6 & RKD & Altered andesite & 4- 6 & $0-25$ & 23 & $42-52^{*}$ & $5-5 \cdot 5$ & Digging \\
\hline 7 & Quarry on dam „Kalica“ & Altered diabase & $6-10$ & $0-25$ & 26 & Assumption $50^{*}$ & $5 \cdot 5$ & Ripping \\
\hline 8 & $\begin{array}{l}\text { Quarry for dam } \\
\text { „Bargala“ }\end{array}$ & Granite & $10-35$ & $50-60$ & $25 \cdot 4$ & $\begin{array}{c}133-239 \\
(\text { average } 178) \star\end{array}$ & $6-6.5$ & Blasting \\
\hline 9 & Quarry for dam „Kozjak“ & $\begin{array}{l}\text { Marbleized } \\
\text { limestone }\end{array}$ & 45 & $60-82$ & $27.4-28.4$ & $\begin{array}{c}75-87^{\star} \\
(\min 40 \max 137)\end{array}$ & $3-3 \cdot 5$ & Blasting \\
\hline 10 & $\begin{array}{c}\text { Tunnel } 9 \\
\text { RKD }\end{array}$ & $\begin{array}{l}\text { Albite-epidote- } \\
\text { muskovite schist }\end{array}$ & $10-30$ & $55-60$ & 26 & $\begin{array}{c}\text { Assumption } \\
2-4^{\star \star}\end{array}$ & 4-5 & Blasting \\
\hline 11 & Tunnel 10 RKD & same & $20-100$ & $41-100$ & 26 & same $e^{\star \star}$ & $4-5$ & Blasting \\
\hline 12 & $\begin{array}{l}\text { Quarry for dam, } \\
\text { Oraovichka river: }\end{array}$ & Amphiboli-te & $10-50$ & $45-72$ & $26.63-27$ & $88-149^{*}$ & $5-6$ & Blasting \\
\hline 13 & Dam “Studen-chica“ & Phillitoides & $3-5$ & $0-10$ & $23-24$ & $\begin{array}{l}\text { Assumption around } \\
2 \mathrm{Mpa}^{\star}\end{array}$ & $2-2.5$ & Digging \\
\hline 14 & $\begin{array}{l}\text { Bridge Dlabochica } \\
\text { (RKD) }\end{array}$ & $\begin{array}{l}\text { Albite-sericite } \\
\text { schist (Sab) }\end{array}$ & $2-4$ & $0-10$ & 25.6 & $1-2.1^{\star \star}$ & $3-4$ & Digging \\
\hline 15 & Bridge Chankinci (RKD) & Sab & $10-15$ & $55-60$ & 26.8 & $2-4^{\star \star}$ & $4-4 \cdot 5$ & Blasting \\
\hline 16 & $\begin{array}{l}\text { Dirferent zone for } \\
\text { magistral road M-5 }\end{array}$ & Micaschist & $3 \cdot 3$ & $0-10$ & 26 & same ${ }^{\star \star}$ & $2-3$ & Digging \\
\hline 17 & Zone for M-5 & Micaschist & $6-8$ & $10-21$ & 25.8 & same $^{\star \star}$ & $2-3$ & Ripping \\
\hline 18 & Zone for $M-5$ & Micaschist & $10-12$ & $25-30$ & 25 & $1.79-2.51$ & $2-3$ & Blasting \\
\hline 19 & $\begin{array}{l}\text { Cut for bridge from RKD } \\
\text { km } 46+950\end{array}$ & tuffs & $\begin{array}{l}\text { massive } \\
1.5 \mathrm{~m}\end{array}$ & $80-90$ & $23.06-23.62$ & $8-17^{*}$ & $3-3 \cdot 5$ & $\begin{array}{l}\text { Combined } \\
\text { Ripping - } \\
\text { Blasting }\end{array}$ \\
\hline 20 & Bridge at $48+803$ RKD & Andesite tuff & $15-20$ & 52 & $20.15-22.05$ & $9 \cdot 5-16^{*}$ & $4-4 \cdot 5$ & Blasting \\
\hline 21 & RKD $49+540$ & Andesite & $16-20$ & 54 & $24.1-25.8$ & $55^{\star}$ & $5-5 \cdot 5$ & Blasting \\
\hline 22 & RKD & Sab & $18-25$ & $64-77$ & $25 \cdot 8-27.3$ & $23-25^{*}$ & $4-4 \cdot 5$ & Blasting \\
\hline 23 & Highway Skopje-Tetovo & Marl to marlstones & $10-15$ & $45-50$ & $\begin{array}{c}21.47 \\
-21.54\end{array}$ & $0.32-0.52^{\star *}$ & 2 & Digging \\
\hline 24 & Same & Marly sandstones & $10-15$ & 49 & $20.64-22.2$ & $0.43-0.48^{\star \star}$ & 2.5 & Digging \\
\hline 25 & $\begin{array}{l}\text { Quarry „Micro- } \\
\text { granulate“ }\end{array}$ & Limestone & $5-8$ & $30-45$ & 27.2 & (average $=74 \mathrm{MPa}^{\star}$ ) & 3 & Ripping \\
\hline 26 & $\begin{array}{l}\text { Surface mine for copper } \\
\text { „Buchim“ SMCB }\end{array}$ & Andesite & $20-50$ & 82 & 27.03 & $7.68^{\star \star}$ & $5-6$ & Blasting \\
\hline 27 & SMCB & Gneiss & $10-30$ & 60 & 25.42 & $3.17-4 \cdot 992^{\star \star}$ & $5 \cdot 5-6$ & Blasting \\
\hline 28 & SMCB & Gneiss with ore & $30-50$ & 59 & 30.47 & $4 \cdot 52-8.9^{\star \star}$ & 6 & Blasting \\
\hline 29 & $\begin{array}{c}\text { Access road to dam } \\
\text { „Lojane“ }\end{array}$ & $\begin{array}{c}\text { Altered } \\
\text { granodiorites }\end{array}$ & $10-20$ & $11-39$ & 26.32 & $1.793-3.992^{\star \star}$ & $5 \cdot 5-6$ & Ripping \\
\hline 30 & $\begin{array}{c}\text { Quarry } \\
\text { „Rajchica“-R }\end{array}$ & Carbonate breccia & $6-10$ & $0-10$ & 22.3 & $10-14^{*}$ & 1.5 & $\begin{array}{l}\text { Digging - } \\
\text { Ripping }\end{array}$ \\
\hline 31 & $\mathrm{R}$ & Sandstone & 4-6 & $25-30$ & $24 \cdot 3$ & $39-46^{\star}$ & 4 & Ripping \\
\hline 32 & $\mathrm{R}$ & Limestone & $200-600$ & $75-90$ & 26.2 & $68-92^{*}$ & 3 & Blasting \\
\hline 33 & Cut on RKD & Sab & $60-100$ & $25-50$ & 25.8 & $1-2.1^{\star \star}$ & $3-4$ & Ripping \\
\hline 34 & $\begin{array}{l}\text { Zones along crude oil } \\
\text { pipeline } \\
\text { Solun-Skopje (OPSS) }\end{array}$ & Marlstones & $40-60$ & $25-50$ & $22.2-24$ & $5^{-18 *}$ & 2 & $\begin{array}{l}\text { Digging - } \\
\text { Ripping }\end{array}$ \\
\hline 35 & OPSS & Sandstones & $80-150$ & $75-90$ & $23.2-25.2$ & $25-44^{\star}$ & $3 \cdot 5-4$ & Ripping \\
\hline 36 & OPSS & Altered diabasses & $20-40$ & $<25$ & $25 \cdot 4-26$ & $5-13^{*}$ & 4 & $\begin{array}{l}\text { Digging - } \\
\text { Ripping }\end{array}$ \\
\hline 37 & OPSS & $\begin{array}{l}\text { Partially altered } \\
\text { diabasses }\end{array}$ & $8-10$ & $45-60$ & $25.6-26.2$ & $45-60^{*}$ & 6 & Ripping \\
\hline
\end{tabular}

Note: *-data for compressive strength ( $\sigma c),{ }^{* *}$-data for Strength index (Js)

Table 1 Database for classification, with data for applied excavation method 


\begin{tabular}{|c|c|c|c|c|c|c|c|}
\hline \multirow{2}{*}{ Parameter } & \multicolumn{7}{|c|}{ Class } \\
\hline & I & II & III & IV & $\mathbf{V}$ & VI & VII \\
\hline $\begin{array}{l}\text { 1.Compressive } \\
\text { strength ( } \sigma c)\end{array}$ & \multirow{2}{*}{$\begin{array}{l}\text { Non-coherent } \\
\text { soils }\end{array}$} & $<1$ & $1-5$ & $5-10$ & $10-30$ & $30-70$ & $>70$ \\
\hline $\begin{array}{l}\text { Point load strength } \\
\text { index Is }(\mathrm{MPa})\left(^{\star}\right)\end{array}$ & & $<0.1$ & $0.1-0.7$ & $0.7-1.2$ & $1.2-2$ & $2.5-4$ & $>4$ \\
\hline Rating & 0 & 3 & 5 & 8 & 10 & 12 & 20 \\
\hline $\begin{array}{l}\text { 2.Hardness } \\
\text { according the } \\
\text { Moss scale }\end{array}$ & Soil materials & $1-1.5$ & $1.5-2$ & $2-3$ & $3-5$ & $5-6$ & $>6$ \\
\hline $\begin{array}{l}\text { Value of } \\
\text { SHRV }\end{array}$ & $(\mathrm{SHRV}<10)$ & $10-13$ & $13-17$ & $17-26$ & $26-35$ & $35-50$ & $>50$ \\
\hline Rating & 1 & 3 & 5 & 8 & 10 & 15 & 20 \\
\hline $\begin{array}{l}\text { 3.Unit weight } \\
\gamma\left(\mathrm{kN} / \mathrm{m}^{\wedge} 3\right)\end{array}$ & $12-15$ & $15-18$ & $18-22$ & $22-24$ & $24-27$ & $27-30$ & $>30$ \\
\hline Points & 3 & 4 & 6 & 8 & 12 & 15 & 20 \\
\hline $\begin{array}{l}\text { 4.Joint spacing } \\
\text { Ls }(\mathrm{cm})\end{array}$ & $\begin{array}{l}\text { Non-coherent } \\
\text { soils }(* \star)\end{array}$ & $<2$ & $2-6$ & $6-10$ & $10-30$ & $30-200$ & $>200$ \\
\hline RQD(\%) & 0 & $0-10$ & $10-25$ & $25-50$ & $50-75$ & $75-90$ & $90-100$ \\
\hline Rating & 0 & 4 & 8 & 13 & 16 & 18 & 25 \\
\hline \multirow[t]{2}{*}{$\begin{array}{l}\text { 5. Condition of } \\
\text { fractures } \\
(\star \star \star) \\
(\star \star \star \star)\end{array}$} & $\begin{array}{l}\text { Non-coherent } \\
\text { soils }\end{array}$ & $\begin{array}{l}\text { 1.Smooth } \\
\text { 2. Continual } \\
\text { 3. Aperture } \\
>10 \mathrm{~mm} \text {, } \\
\text { 4.Soft infill } \\
\text { (thickness } \\
>10 \mathrm{~mm} \text { ) }\end{array}$ & $\begin{array}{l}\text { 1. Smooth } \\
\text { 2. Continual } \\
\text { 3. Aperture } \\
\text { 5-10 mm, } \\
\text { 4.Soft infill } \\
\text { (thickness } \\
\text { 5-10 mm) }\end{array}$ & $\begin{array}{l}\text { 1.Medium rough } \\
\text { 2. Continual } \\
\text { 3. Aperture } \\
\text { <1-2 mm, } \\
\text { 4. Very altered } \\
\text { walls }\end{array}$ & $\begin{array}{l}\text { 1.Rough } \\
\text { 2. Continual } \\
\text { 3.Aperture } \\
\text { <1mm, } \\
\text { 4.Very altered } \\
\text { walls }\end{array}$ & $\begin{array}{l}\text { 1. Rough } \\
\text { 2. Continual } \\
\text { 3. Aperture } \\
\text { <1mm, } \\
\text { 4.Weakly } \\
\text { altered walls }\end{array}$ & $\begin{array}{l}\text { 1.Very rough } \\
\text { 2.Discontin. } \\
\text { 3.Without } \\
\text { aperture } \\
\text { (tight) } \\
\text { 4.Unaltered } \\
\text { walls }\end{array}$ \\
\hline & type 1 & type 2 & type 3 & type 4 & type 5 & type 6 & type 7 \\
\hline Rating & 0 & 1 & 2 & 4 & 7 & 8 & 15 \\
\hline $\begin{array}{l}\text { Total rating as a } \\
\text { score of individual } \\
\text { ratings } \\
\text { (ERMR) }\end{array}$ & $\ll 10$ & $10-25$ & $26-40$ & $41-50$ & $51-60$ & $61-80$ & $81-100$ \\
\hline $\begin{array}{l}\text { Possible method of } \\
\text { excavation }\end{array}$ & Easy digging & $\begin{array}{c}\text { Usual } \\
\text { conditions for } \\
\text { digging }\end{array}$ & $\begin{array}{l}\text { Very hard } \\
\text { digging, easy } \\
\text { ripping }\end{array}$ & Ripping & $\begin{array}{l}\text { Ripping-blast } \\
\text { nto loesen }\end{array}$ & Blasting & $\begin{array}{l}\text { Extremely hard } \\
\text { conditions for } \\
\text { blasting }\end{array}$ \\
\hline
\end{tabular}

\section{Table 2: Parameters and range of values in ERMR classification system}

The used parameters in classification procedure, range of values and ratings for each class is shown in table 2.

(*) Gradation of the strength of intact parts is partially changed after Weaver 1975,

$\left.{ }^{\star *}\right)$ For non-coherent soils (coarse grained sediments), where the excavation is difficult because of possible presence of large boulders, some otrer classification system can be applied that can be used simmilar as for loading of blasted rock material.

$(* * *)$ The condition of fractures can be defined as combination of more characteristics, as continuity, type of infill, roughness or aperture, and for mathematical calculation a given class is defined as type 1 to type 7 , for which arbitrated value from 1 to 7 is assigned.

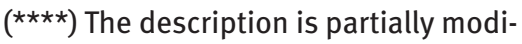
fied in relation to Bienawski's 1989 classification

In order to perceive the degree of correlation of the ERMR classification with other systems, in this paper two examples are given:
- Correlation ERMR $=f(R M R)$

- Correlation ERMR $=\mathrm{f}(\mathrm{Vp})$

Where:

RMR - Rock Mass Rating system according Bieniawski

Vp -value for longitudinal seismic waves

Straight line regression model with high correlation coefficient $(r)$ is presented on Figures 1 and 2. 


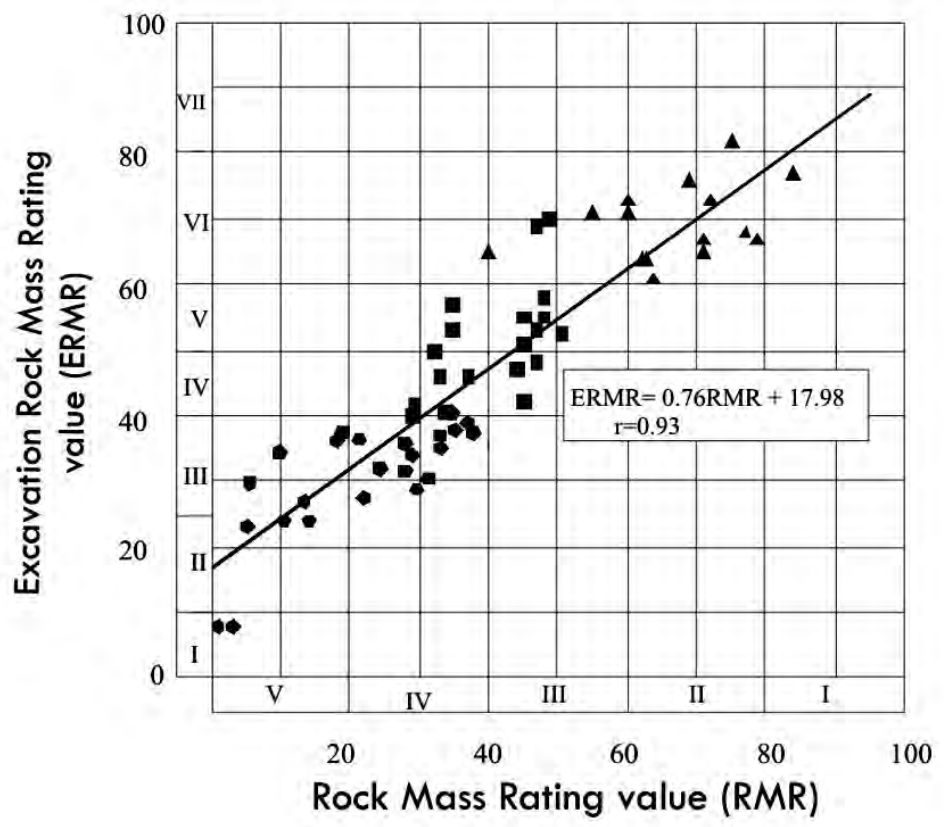

Figure 1. Correlation between ERMR and RMR systems

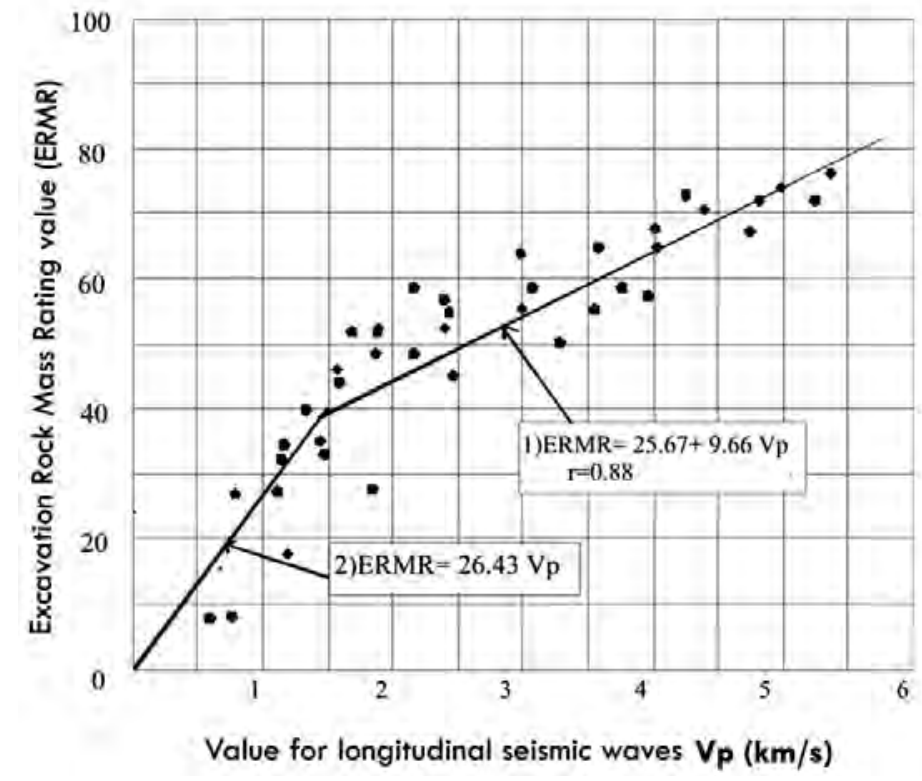

Figure 2. Correlation between ERMR an value of elastic longitudinal seismic Vp-waves

As special cases at classification of rock masses the next ones can be numbered:

- For coarse grained non-coherent rock masses classification with large boulders, depending on the conditions, the boulders can be moved away, or secondary blasted (the payment is defined separately).
- For weak claylike rocks without visible joints, for average distance and condition of fractures a value of points $=0$ is adopted.

- In certain cases, selection of excavation method depends on the available mechanization, so classes III and IV should be treated as interclass (example, if we have a bulldozer type D9 or D9G, the media will be excavated with hard ripping, and in opposite we will apply blasting procedure).

- In certain cases, selection of excavation method depends on the morphology of the terrain and the type of structure (example, ripping is rarely used in tunnelling, in difficult morphological conditions and tight excavation, as excavation for bridge foundations and concrete dams, even if the characteristics of the media allow it).

- In certain cases, where on short distances different characteristics of the rock mass change very often, combined way of excavation can be used

- In cases where conditions for blasting are extremely hard, where the specific consumption of explosives is increased and where closely spaced blast holes are needed, special cases for payment shall be agreed.

From all given examples, it is obvious that for every specific problem valuing of other external factors is needed, which can affect choice of method of excavation, and which are not included in the criteria of the classification itself. Also, it is desirable to make comparisons of the classification with some of the other systems, in other word their correlation.

\section{Practical application of ERMR System}

The proposed classification method can be used at a first place to choose adequate technology of excavation. It can be noted that blasting is required when ERMR values are higher than $E R M R=60$. Successful ripping is generally achieved for rock masses with ERMR values between $E R M R=40-60$. However, sometimes, alternative of ripping and blasting are possible, and some time using of excavation with hydraulic breakers or secondary blasting can be necessary.

For example, the data form Figure 2, 
indicates that two general zones on the diagram can be divided. Curve 2 is for cases where the media shall be excavated with digging, while the curve 1 covers the cases of ripping and blasting.

Connected with ERMR value, the recommendations for excavation equipment is given in Table 3.
The diagram gives a range of values as a lower and upper envelope. It is clear that this can be only method for fast prognosis for cost of excavation, while the tendering price or real price of excavation shall be prepared according to market and field conditions. recommended that the system should have primary importance for phases of designing before level of Main Design. Having in mind that the empirical methods are based on certain level of experience, it shall be a subject to critical reviewing in time, and should be used in combination with other methods.

\begin{tabular}{|c|c|c|c|c|c|}
\hline ERMR value & $<10$ & $10-25$ & $26-40$ & $41-50$ & $51-60$ \\
\hline $\begin{array}{c}\text { Possible } \\
\text { mechanization }\end{array}$ & $\begin{array}{c}\text { Excavator type } \\
\mathrm{RH}_{5}\left(^{*}\right)\end{array}$ & $\begin{array}{c}\text { Excavator } \\
\text { Type RH8 }\end{array}$ & $\begin{array}{c}\text { Excavator RH9 } \\
\text { or buldzoer } \\
\text { D7 }\end{array}$ & $\begin{array}{c}\text { Buldozer type } \\
\text { D8/D7 }\end{array}$ & $\begin{array}{c}\text { Buldozer type } \\
\text { D9/D9G }\end{array}$ \\
\hline
\end{tabular}

Table 3: ERMR value and suggested excavation equipement

(*) Note- It is possible that some types of machines recommended in Table 3 are no longer manufactured, so similar machines for excavation for the named classes can be used.

From practical point of view, it is also important to establish some kind of connection between costs for excavation and rock mass class. Based on experiences and tendering data from several projects, one correlation is established between ERMR value with unit price for excavation per meter cubic (Figure 3).

\section{Conclusions}

Based on numerous investigations for specific structures Excavation Rock Mass Rating classification system is developed. All rock masses are divided in seven basic classes, where for each one of them recommendations are given for possible method of excavation, mechanisation etc.

The system well correlates with other classification systems (RMR value, as well as with the speed of longitudinal seismic Vp-waves propagation). In order to proper apply the current and suggested methods in the paper, it is

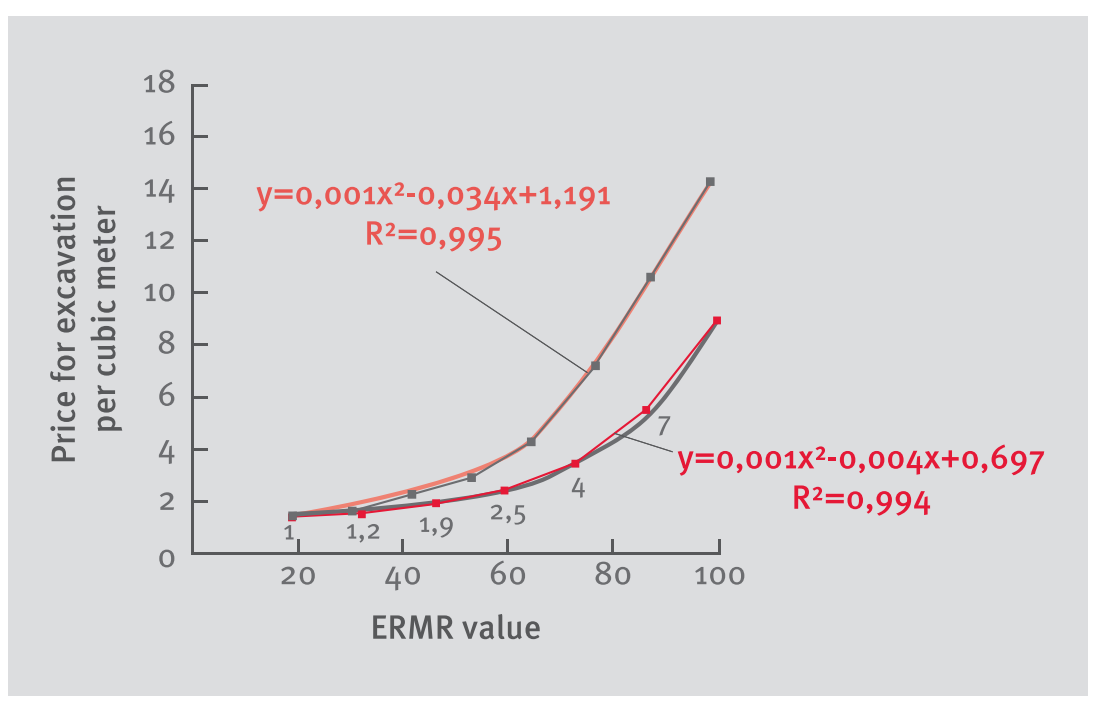

Any how, it can help a lot in defining of technology of excavation, selection of excavation equipotent and cost of excavation.

\section{References}

Abdulatiff O.M., Cruden D.M.: The relationship between rock mass quality and easy of exavation, Bulletin of IAEG No 28, Paris, 1983

Bieniawski Z.T.: Classification of Rock Masses for Engineering: The RMR System and future trends. Comprehensive Rock Engineering, 1993

Franklin A.J.: Observations and Tests for Engineering Description and Mapping of Rock, Second Congress of the International Society for Rock Mechanics, Beograd, 1970

Tsiambaos G., Saroglou H.: Assessment of ease of excavation using Excavation Rock Mass Rating System (ERMR), Bulletin of Engineering Geology and the Environment, The official journal of the IAEG, 2009

Figure 3. Prediction of unit price per meter cubic using ERMR value 